(c) The Author(s), 2021. Published by Cambridge University Press. This is an Open Access article, distributed under the terms of the Creative Commons Attribution licence (http://creativecommons.org/licenses/by/4.0/), which permits unrestricted re-use, distribution, and reproduction in any medium, provided the original work is properly cited. doi:10.1017/S1474746421000397

\title{
Income Support in an Eco-Social State: The Case for Participation Income
}

\author{
Michael McGann* (1) and Mary P. Murphy** \\ *Maynooth University Social Sciences Institute, National University of Ireland Maynooth, Ireland \\ E-mail: Michael.mcgann@mu.ie
}

**Department of Sociology, National University of Ireland Maynooth, Ireland

E-mail: mary.p.murphy@mu.ie

Contemporary models of welfare capitalism have frequently been critiqued about their fit-for-purpose in provisioning for people's basic needs including care, and longer-term ecological sustainability. The Covid-19 pandemic has also exposed the need for better institutions and a new welfare architecture. We argue a post-productivist eco-social state can deliver sustainable well-being and meet basic needs. Arguing Universal Basic Services are an essential building block and prerequisite for a de-commodified welfare state, we focus on examining the form of income support that might best complement UBS. The article develops, from the perspective of feminist arguments and the capabilities approach, a case for Participation Income. This, we argue, can be aligned with targeted policy goals, particularly reward for and redistribution of human and ecological care or reproduction and other forms of socially valued participation. It may also, in the short term, be more administratively practical and politically feasible than universal basic income.

Keywords: Capabilities, eco-social policy, universal basic services, participation income, post-productivism.

\section{Introduction}

Rarely do pandemics and other emergencies lead to major reconfigurations in social policy (Castles, 2010). Nonetheless, Gough (2020) argues that the social policy innovations put in place in response to the Covid crisis 'have begun to crack the carapace of business as usual' to provide a glimpse into dynamics of large-scale change needed to inform our future. One feature of how liberal welfare states such as the UK and Ireland responded to the crises is that they introduced major, albeit temporary, re-adjustments to the balance between what Brodkin and Larsen (2013: 60) characterise as the 'regulatory, compensatory, and enabling' dimensions of welfare. In many cases, regulatory demands and conduct conditions were all but suspended while compensatory benefits were increased and made easier to access (Hick and Murphy, 2021). The shuttering of economies also motivated much commentary about the ecological sustainability of contemporary models of welfare capitalism and their 'fit-for-purpose' in meeting essential needs (see Laurent, 2020; Wignaraja and Horvath, 2020), resonating with a pre-pandemic literature that, under the rubric of various concepts, discussed what might be the components of a 'post-productivist' (Fitzpatrick, 2004), 'sustainable' (Hirvilammi and Koch, 2020), or 'eco-social' (Koch, 2018) welfare state; namely, one oriented not by 
productivity and economic growth but by a new welfare architecture with sustainable well-being and care at its centre.

The case for an eco-social welfare state has been advanced by numerous scholars within the comparative welfare states and sustainability fields (eg. Fitzpatrick, 2004; Koch and Fritz, 2014; Gough, 2015; Hirvilammi and Koch, 2020). However, as Bohnenberger observes, the role of social policy in enabling transitions towards a sustainable political economy 'is often only a side note' (2020: 596) within the literature on decarbonisation and sustainability, while Koch observes that environmental concerns similarly 'remain largely ignored in social policy debates' (2018: 42). In the context of income supports, 'sustainability' is frequently appraised in fiscal rather than social or ecological terms (Stamm et al., 2020). A notable exception are proposals for an Unconditional Basic Income (UBI), which many see as a means of "breaking the "unholy link" (Pinto, 2020: 269) between economic security, employment and the associated environmental impacts. In this article, however, we revive interest in the concept of a Participation Income (PI) as an alternative social security reform proposal that, when allied to Universal Basic Services, can go far towards progressing an eco-social reform agenda.

The case for a PI was first made by Atkinson (1996), who proposed that it was more politically palatable in the short-term but which could open the doorway to unconditional welfare as a stepping-stone to UBI. Recently, however, PI and related proposals such as an 'ecological transition income' have received renewed attention as reforms worthy of support in their own right from post-productivists who remain concerned that a UBI may foster consumerism and unsustainable consumption (Pérez-Muñoz, 2018; Swaton, 2018). We further develop this argument, building the normative case for PI, elaborating its contribution to an eco-social recalibration of welfare, and briefly addressing issues of administrative and political feasibility.

We proceed by making the case for a post-productivist, eco-social state and defining what we mean by sustainable well-being. We then focus on what form of income support best complements this form of sustainable provision for basic needs, arguing that UBI overclaims on various fronts and unpacking the case for $\mathrm{PI}$ as preferable from both a feminist and capabilities-promoting eco-social policy perspective. Arguments against PI often focus on the administrative difficulties of determining eligibility and entitlement, of establishing the legitimacy of various forms of participation, and of determining the degree of conditionality that might be adopted. We first develop a logic for an appropriate degree of conditionality and then develop normative and conceptual arguments for what might be valid forms of participation. We conclude by considering the politics of reform. Acknowledging that administrative difficulties of determining eligibility and entitlement remain, we argue they can be overcome through carefully calibrated co-creation implementation structures and that these are necessary if PI proposals are to avoid becoming another form of residualised welfare that stigmatises claimants through invasive bureaucratic assessments of household means and claimant behaviour.

\section{Towards a post-productivist, eco-social state}

Notwithstanding important differences between welfare regimes in terms of the degree to which they 'commodify' labour, all are essentially productivist in foundation. That is, they can be understood as a series of attempts to reconcile social security with promoting an 
agenda of productivity growth orientated by the assumption 'of a virtuous circle' (Hirvilammi, 2020: 391) between social and economic policies. This is most pronounced in the workfare-oriented activation policies of liberal welfare regimes, which render participation in employment an important end of social policy (cf. Fitzpatrick, 2004) and the principal 'marker of the dutiful, responsible citizen' (Patrick, 2017: 294). However, even so-called 'capacitating' or 'enabling' welfare state models rely on the dividend of future productivity growth to underwrite increases in welfare spending; repositioning social policy 'as a 'productive factor"' (Laruffa, 2020: 2) for 'mobilising human resources and stabilising economic activity' (Hirvilammi, 2020: 391).

A common criticism of this productivist paradigm is that it reduces social policies to tools for fostering economic growth 'rather than full citizens with real freedom to lead a life they have reason to value' (Bonvin and Ziegler, 2020: 1, 2). As Fitzpatrick (2004: 218) argues, the continuing 'fetishisation of productivity growth' makes achieving anything 'more than modest' forms of gender equality and sustainability extremely difficult. This is due to its inability to account for the value of essential reproductive activities, such as caring for people, the environment, or political institutions, unless those activities can be monetised into surplus economic value (Barry, 2019). Reproductive activity, which Fitzpatrick applies to both care and ecological work, carries economic value as it sustains the human, emotional and environmental resources upon which productivity depends. However, 'economic value' is not the primary reason why people undertake reproductive work nor can its value be captured in commodity terms. The value of reproductive work which we would extend to include contributions to sustaining democratic institutions via participation in politics and civil society - transcends the economic.

Beyond misrecognising reproductive work, productivist regimes carry a substantial ecological footprint as highlighted by research on sustainability and degrowth (Gough, 2013, 2015; for a systematic review see Haberl et al., 2020). Even if economic growth could be decoupled from emissions, this is unlikely to happen fast enough to contain global warming within the one-and-a-half to two degrees threshold required to avoid catastrophic climate change (Hirvilammi, 2020). Structural political economic changes will therefore be required to reduce rather than 'green' consumerism and economic growth (Pinto, 2020).

The importance of 'countervailing social policies' (Gough, 2013: 192) in mitigating the distributive impacts of decarbonisation policies on disadvantaged groups is already well acknowledged in debates on sustainability (cf. Koch, 2018). However, the concept of eco-social welfare goes beyond understanding social policies as safety nets for cushioning the social impacts of decarbonisation to recognising that social policies themselves 'have high leverage on the level of carbon emissions' (Bohnenberger, 2020: 596). It directs attention from the social consequences of environmental policies to the environmental consequences of welfare systems that enable many 'to participate in production and consumption patterns that are, all other things being equal, environmentally harmful' (Koch and Fritz, 2014: 683). Whereas productivism subsumes welfare states within the global economy, eco-social policy calls for welfare states to be seen 'as embedded in ecosystems' (Hirvilammi and Koch, 2020) and constrained by ecological limits. But before we examine how a new welfare architecture can enable recalibration on such a post-productivist trajectory, we need to first explore what we mean by sustainable well-being and its implications for how we understand the nature of the economy and value of work. 


\section{Sustainable well-being: capabilities, needs, and basic services}

Conceptualising 'feasible forms of wellbeing' (Bonvin and Ziegler, 2020: 3) is necessarily unavoidable for a critical social science of the political economy, not least because an understanding of wellbeing is implicit to the very idea of a welfare state. One of the most prominent accounts of sustainable wellbeing is Doyal and Gough's (1991; Gough, 2015) theory of human need, which establishes a set of fundamental autonomy- and healthrelated needs that 'must be satisfied to some degree before actors can effectively participate in their form of life to achieve any other valued goal' (Gough, 2015: 1197). It also specifies the kinds of resources and conditions, or 'universalizable preconditions' (Gough, 2015: 1197), that societies must provide if these basic health, autonomy, and participation needs are to be met. These include things like food and water, housing, healthcare, education and broadly resemble the kinds of goods and services provided by 'essential workers' during the pandemic (Gough, 2020).

A closely related theory of wellbeing that we draw upon to develop the case for PI is the capability approach (CA), first advanced by Sen and subsequently developed by Nussbaum, Anderson, and others. Nussbaum's (2001) development of the CA is particularly significant because, unlike Sen's account ${ }^{1}$, it offers a clear articulation of ten central functional capabilities that universally ground people's freedom to achieve combinations of 'doings' and 'beings'. Nussbaum also emphasises the importance of democratic deliberation and political justification in filling out the details of which capabilities matter most, offering her list of central capabilities - which includes capabilities for life, bodily health and integrity, senses, imagination and thought, practical reason, play and control over one's environment (among others) - as something to be continuously 'contested and remade' (Nussbaum, 2001: 77). Anderson's extension pushes the relationship between democracy and capabilities even further, positioning the CA as a relational theory of democratic equality that defines the preconditions needed 'to create a community in which people stand in relations of equality to others' (1999: 289). What matters from the point of view of equality, Anderson argues, is not simply resource distribution but more critically that people stand in social relations where 'mutual consultation, reciprocation, and recognition' are taken 'for granted' (1999: 313). Her concept of democratic equality incorporates both a public and private dimension. The former captures those capabilities 'necessary for functioning as an equal citizen' (Anderson, 1999: 317), including both political agency (voting, political speech) and the sphere of civil society, which Anderson argues is vital to an active understanding of citizenship. The private dimension of democratic equality concerns people's freedom from entanglement in 'oppressive social relationships' (Anderson, 1999: 316) within the domestic sphere, and is contingent on capabilities for sexual autonomy, bodily integrity, and so forth which in turn depend on people having 'effective access' to the means (e.g. food, shelter, clothing, medical care) for sustaining their biological existence.

There are important differences between need theory and the CA that space does not permit us to address here (although see Gough, 2014). However, these are less significant than what the theories share, which is a commitment to a pluralist but nonetheless universalisable theory of wellbeing that sets important limits on economic growth. Basic needs and central human capabilities are non-substitutable preconditions for flourishing. 'One domain of need-satisfaction cannot be traded off against another', as Gough argues (2019: 535). They are also satiable in that the amount of goods and services needed to 
secure basic needs and central capabilities eventually plateaus, after which point the value of further consumption sharply diminishes. In other words, economic activity has value only insofar as it supports the 'shared claim of all [within and between generations] to the basic capability to lead worthwhile lives' (Anand and Sen, 2000: 2030). This brings 'a critical edge' (Sayer, 2019: 43) to our understanding of the nature of economies. In place of the economy as a system for regulating the production and exchange of substitutable commodities according to price and demand, the yardstick of value becomes whether economic systems provide 'the key things that people need to have and do to be able to flourish' (Sayer, 2019: 42). Recognising this challenges conceptions of the economy 'as a single homogenous zone' (Leaver and Williams, 2014: 220) and suggests treating the economy instead as 'a network of "systems of provision"' (Gough, 2019: 535) for supplying foundational goods and services essential 'to everyday life' (Leaver and Williams, 2014: 220). This idea of the foundational economy has been proposed from the perspective of the CA (Sayer, 2019) and needs theory (Gough, 2019) alike, with Gough suggesting that it takes two distinct forms: the material foundational economy of pipe and cable utilities; transport infrastructure; food production, processing, and distribution; and banking services, much of which remains within the domain of the market, and the providential foundational economy of predominantly state-run public services such as healthcare, education, social care, police and emergency services. What characterises both forms, however, is that they 'provide collective, shared services' for mutual benefit through provisioning systems that are irreducible 'to the purchase of individual commodities' (Gough, 2019: 537). As Leaver and Williams argue, foundational goods and services are collectively consumed 'by all citizens regardless of income' and their cost and quality 'are key determinants of mass welfare' (2014: 220).

This does not preclude the possibility of market provision, although several arguments have been advanced as to why public provision is preferable for reasons of equity, efficiency, solidarity, and sustainability (Gough, 2019: 538-541; Coote and Percy, 2020: 32-56). This has led to the development of the concept of Universal Basic Services (UBS) as a way to move from reliance on 'the neoliberal formula of individualised consumption within a market-based system' (Coote and Percy, 2020: 7-8) towards a system of collective mutual interdependence through 'sharing resources and acting together' (Gough, 2019: 540). Coote and Percy conceive of UBS as a 'virtual income of public services' (2020: 3) that contributes to de-commodification by reducing people's reliance on the market to meet essential needs. Gough argues that this in turn promotes equality since, 'in the absence of public provision', people on low incomes would need to spend 'the majority of their income' on meeting basic needs (2019: 539). Moreover, public provisioning systems may be better equipped than market systems to promote sustainable consumption and to meet needs through 'less carbon intensive' production, especially when anchored in localised, communal supply chains (Sayer, 2019: 45).

At the heart of the concept of UBS is a mission to transform the way services are provided, to put people in control, and to build a new role for the state. Coote and Percy offer a framework that provides a set of guiding principles, and an evidence-based rationale, to prove that collective provision yields far better results than market transactions in terms of equity, efficiency, solidarity and sustainability. They offer not a guidebook, but principles or features; access to services that meet one's needs as a matter of right, citizen participation so that services are 'controlled by the people who need and use them' (Coote and Percy, 2020: 5), and diverse models of ownership. The 
state retains responsibility for ensuring equal access, collecting and distributing resources, setting and enforcing quality standards and co-ordinating services across different areas of need. Thus, the concept of UBS synergises with the concept of a foundational economy and its focus on the collective and ecological provision of services (Coote, 2000). This idea of a foundational economy of UBS recovers the importance of welfare states in securing the conditions for collective wellbeing, although Coote and Percy are careful to point out that some needs may continue to be provided for via the market and that UBS should be 'supported rather than always directly provided by the state' (2020: 5). Moreover, in a recent extension of their work, Coote (Coote, A, n.d.) argues that UBS requires not just the provision of services but also 'an income guarantee to ensure that everyone has sufficient disposable cash'. The more UBS are realised through market rather than public provision the higher this income guarantee will need to be. Nonetheless, even in the context of widespread public provision, people will still need some level of disposable income if they are to enjoy central capabilities for play, senses, imagination and thought, and so on that are connected to the pursuit of varying life plans and exercise of agency and choice. Consequently, as Coote and Lawson (2021) argue, income supports and UBS are best thought of 'as two sides of the same coin' rather than conflicting alternatives.

Below, we ask what kind of income support reform might best complement UBS. We first examine the growing calls for a UBI before proposing the concept of a PI as an alternative reform pathway for securing a wider conception of income supports that can interact with UBS to enable people to live, work and care differently.

\section{A complementary form of income support}

It is striking the degree to which UBI has been positioned as 'the answer to the inequalities exposed by Covid-19' (Wignaraja and Horvath, 2020). Proponents argue that unconditional benefits can promote transitions towards a more sustainable welfare state (Pinto, 2020); enhance gender equality by improving women's bargaining position in the labour market and promote part-time working arrangements among men (McKay, 2001); and generally liberate people from market dependency (van Parijs, 1995). Indeed, proposals for a UBI are variously defended by post-productivists committed to reducing economic growth as well as neoliberals who view UBI as a means of stimulating consumption in the face of widespread unemployment and the automation of work. However, despite its broad appeal, a range of criticisms has been advanced of UBI as a progressive reform of income supports. For our purposes, we shall focus on those related to UBI's capacity to adequately value reproductive labour and to promote more sustainable patterns of economic participation.

Concerning gender equality, several feminists, including Lombardozzi (2020), argue that the transformative capacity of $U \mathrm{BI}$ as a panacea to the crises of work and care may be overestimated. For instance, it is unclear how an unconditional payment would compensate those who provide care over those who do not. Given the current gendered division of productive and reproductive labour, Robeyns (2001: 103) worries that a UBI risks reinforcing 'traditional gender roles' and may result in more women withdrawing from employment. Panitch (2011) challenges the claim that UBI has substantial de-commodifying effects. Returning temporal autonomy to people over how they choose to spend their time is a key reason why many post-productivists support a UBI. However, the de-commodifying 
potential of an UBI critically depends on how high the benefits are, as well as on whether $\mathrm{UBI}$ is offered as a supplement to, or substitute for, public services. If the latter, even a UBI offering a high income replacement rate would still 'have the effect of forcing people into further market exchanges to satisfy their most basic needs' (Panitch, 2011: 944). This is especially a danger with libertarian justifications that frame UBI as a means of maximising individuals' consumptive freedom rather than welfare bureaucracies determining which services are provided. To this extent, Coote and Percy fear that a UBI may entrench processes of commodification and erode collective solidarity by plugging people 'into a market system that feeds on choice and competition' (2020: 55).

Even where UBI is proposed as complimentary to UBS, it is still unclear whether it will redirect people's time away from employment towards more ecologically sustainable patterns of economic activity, or if recipients will instead use the 'extra income unconditionality' (Pinto, 2020: 269) to boost their consumer purchasing power rather than reduce the proportion of their time working for pay. This concern brings into view questions about the participatory effects of $\mathrm{UBI}$, and the relationship between income supports and collective social labour, by which we mean the contributive work performed by people to meet shared needs whether through paid employment, volunteering, informal or unpaid work. We use the term 'collective social labour' deliberatively to avoid reducing social cooperation to market participation while retaining an emphasis on the value of citizens' performing socially useful work. However, as we argue below, this understanding of social labour incorporates reproductive work that is neither adequately valued nor provided by the market. We ask whether income support needs to be unconditional or are there merits in a conditional income that enables or facilitates and values post-productivist participation?

\section{A participation-based income}

The case for a PI was first made by Atkinson (1996) as a compromise between the aspirations to a UBI and the emerging political acceptability of the workfare model. More recently, the idea of a PI has also been developed by Goodin (2001) as a middle ground between what he perceived as the post-productivist utopia of 'welfare without work' and the neoliberal dystopia of 'work, not welfare.' This characterisation of 'post-productivism' is rightly challenged by Fitzpatrick, who positions post-productivism as a 'post-employment' rather than post-work politics of time 'in which multiple forms of valuable activity, both formal and informal, are identified and nurtured' (2004: 218).

Recognising time-poverty and time-autonomy as central concerns, Fitzpatrick stresses the tensions between balancing time, work and income support, while feminists consistently draw attention to the need for time for care for both men and women (Craig, 2008). Seeking a balance between these possibilities, a PI seeks to widen the range of contributions that are recognised and accommodated as socially useful 'work', and to provide greater temporal autonomy for people to arrange the balance between productive and reproductive time by reducing the financial necessity to participate in the labour market. In this sense, a PI is conceptually distinct from an employment-oriented active labour policy while nevertheless trying to balance the dual objectives of universal protection and social participation.

Below, we briefly unpack three key questions concerning the interrelated challenge of designing a PI that is both administratively and politically feasible: the challenge of 
maintaining reciprocity, of determining what constitutes a valid form of post-productivist participation, and the degree to which the payment is universal or targeted. Effective resolution of each of these administrative and political challenges is required to ensure a $\mathrm{PI}$ can be a form of income support that can be governed and administered without stigmatising recipients.

\section{Maintaining reciprocity}

$\mathrm{PI}^{\prime}$ s key point of departure from a UBI is its retention of an element of behavioural conditionality, or 'conditions of conduct' (Clasen and Clegg, 2007: 167), albeit broadly conceived. As Clasen and Clegg (2007) observe, access to income supports can be variously limited by restricting eligibility to certain categories of people (e.g. age), by restricting eligibility according to people's assessed circumstances (e.g. means-testing), or by withdrawing supports in cases of non-compliance with behavioural obligations such as participation requirements. Atkinson views the retention of behavioural conditionality as a pragmatic acquiescence, citing the difficulty of securing political support for a basic income 'while it remains unconditional on labour market or other activity' (1996: 67). In other words, rendering basic income conditional on participation is a political tactic to smooth the way for a swifter adoption of a UBI and 'implementation by stealth' (Groot et al., 2019: 280). This is how the case for a PI has been broadly construed in the social policy literature. But the participation criterion - depending on how narrow or expansive it is - can be, and is, also defended upon normative grounds: as aligning PI with widely accepted principles of reciprocity in social cooperation (that a UBI violates). This is the principle, as summarised by White (2017), that 'those who choose to share in the benefits created by others' productive efforts should make a reciprocal effort in return.' While UBI advocates often dismiss this principle as a construct of neoliberal paternalists such as Mead, this is a mistake. It is deeply rooted in several influential egalitarian theories of justice and, specifically, in the tradition of social contract theory. Notably, it is foundational to Rawls theory of justice as fairness, which views society - and the welfare state that sustains it - as a regime of social cooperation, or 'collective activity', that 'sustains our efforts and elicits our contribution' (1999: 464 our emphasis). Likewise, in her development of the CA, Anderson views social democracy as a regime of joint cooperative labour in which people's access to the capabilities underpinning equal citizenship depend on their 'fulfilling some role in the division of labour' (1999: 321).

For theorists of equality such as Rawls and Anderson, unconditional welfare fails to respect people's moral autonomy. Enjoying cooperative benefits without contributing in return is to treat fellow citizens as mere instruments to our own wellbeing, undermining the social conditions of our mutual interdependence and equality to each other. This has led some to mistakenly take reciprocity to mean a duty to contribute in the form of paid work. This 'employment-oriented' or 'Conservative Reciprocity Principle' (Anderson, 2004: 246) undergirds contemporary activation policies. However, it rests on a narrow 'productivist' account of social cooperation as sharing in economic growth. The CA embeds a wider understanding of flourishing to recognise myriad forms of socially valuable contributions beyond market participation, including care giving and other forms of social reproduction. Moreover, participating in the labour market is no longer 'considered an end in itself but rather it is positively judged only to the extent that it contributes to human flourishing' (Laruffa, 2020: 6). The obligation to contribute societally 
therefore becomes irreducible to a duty to undertake economic production. This reimagines conditionality, pushing it towards reciprocity and mutual interdependence and away from a narrow producivist rationale focused on job seeking. This reorientation aligns PI with the concept of 'navigational agency' (Claassen, 2018) as well as Beck's (2000: 58) concept of 'a multi-active' society. Both aspire to decouple social esteem and security from paid employment, by socially recognising and accommodating other forms of activity including family and parental work, voluntary work, and political activity. A just society, as Anderson (2004: 251) argues, 'would recognise all of these as fulfilling citizen's obligations of reciprocity.' For example, Swaton (2018) conceives of PI as a form of Ecological Transition Income (ETI) that seeks to accelerate the ecological transition by promoting environmental or social activity compatible with the limits of the biosphere. She argues ETI could be accompanied by tailor-made support for people to launch projects, and that because it advocates broad ecological and democratic belonging it promotes a sense of belonging and cooperation inspired by care and supporting interdependence through solidaristic principles that respect 'equality in difference'. For her, ecology and the social economy are united by citizens' movements and conditions are justified if participation allows for a sense of inclusion and purpose, and less atomisation. Likewise, Pérez-Muñoz (2018) suggests how a Pl could help coordinate environmental reproductive work, through volunteering, social economy, third sector or environmental politics, and/or through refocusing the balance of paid work and active ecological citizenship. We agree that some levels of reciprocity are justified on the grounds that a PI can be better aligned with targeted policy goals, particularly reward for and redistribution of care and ecological work along with other forms of socially valued participation including inputs into local, national and international democratic processes.

\section{What activities constitute post-productivist participation?}

In contrast to the current (work-related) activity-testing of payments, a PI would substantially widen the range and variety of options that are recognised as valued contributions. Pérez-Muñoz, for example, envisages conditioning PI on the performance of 'civic service programmes' ranging from neighbourhood clean-ups, environmental protection and gardening projects, educational programmes, and 'volunteering in homeless shelters' (2016: 175). Swaton (2018) similarly proposes conditioning income support on the performance of community projects such as renovating cultural heritage sites, promoting traditional crafts, setting-up walking trails, raising environmental awareness in schools and providing sustainability advice to businesses. We would argue, however, that the range of activities would need to be considerably widened beyond ecological reproductive work to accommodate other forms of reproductive labour including giving care and forms of voluntary work and political participation that contribute to social reproduction. This aligns PI with the inherent value pluralism of a capabilities-informed theory of wellbeing that Hiilamo and Komp (2018) argue is already evident in some European social assistance programmes, such as the Dutch social assistance program.

The Netherlands 2015 Participation Act was amended in 2017 when a new Article 83 of the Participation Act came into force allowing six municipalities to locally exempt work obligations in lieu of fulfilling social participation 'Quid Pro Quo' requirements. Informed by insights from behavioural economics, Sen's CA, and psychological motivation theories, 
the policy logic was that investing in personal autonomy, trust and intrinsic motivation may enhance people's performance, health and subjective well-being. Obligations can be fulfilled through paid work but also volunteering, further education, caregiving and other health, wellbeing and social integration measures (see Groot et al., 2019: 284). However, under these municipalities' 'trust experiments' (Muffels et al., 2019), these participation requirements are neither strictly monitored nor enforced through sanctions. Instead, citizens are trusted to reciprocate by municipalities, and welfare agencies rely on intrinsically motivating participation through offering demand-oriented opportunities that citizens pursue, not out of compulsion, but because they consider them meaningful and worthwhile. Muffels et al. (2019) argue the innovative policy which shifts from focusing on people's (in)ability to work to investment in people's skills and abilities, opportunities and free choices may mark an irreversible shift in welfare state policy making away from highly conditional social assistance programmes towards less conditional participation or basic income.

In determining forms of socially legitimate forms of participation we can be guided to some degree by the innovative approach in the Netherlands that focused on selfdevelopment (care, education, etc.). However the Dutch approach is still embedded in a wider productivist frame and is less motivated by concerns for ecological reproduction, gender equity, care or democracy. In developing a wider normative approach to determine the boundaries of what might be acceptable participation we are guided by Fitzpatrick's (2003) counterpoints to a productivist approach revolving around norms of paid employment that generate economic value. Fitzpatrick, in defining a postproductivist world, acknowledges that a post-productivist world will include paid employment but insists this must contribute to social reproduction. Post-productivist work will include work whose social value is 'moral, aesthetic, emotional and natural' (Fitzpatrick, 2003: 96) and which contributes to emotional and ecological reproduction. It should also, following Anderson, enable time for democratic work that allows a more careful eco system to be negotiated, nurtured and maintained. Fitzpatrick intimates that such post-productivist work will often be local in nature, be associated with the commons and will replicate the type of work and outcomes generated in the third sector, social economy, co-operatives and through voluntary work. In essence, a PI redistributes time to enable sustainable reproduction while embedding incentives for 'breadwinners' to redistribute their time away from economic production towards socially reproductive labour in a way that a UBI cannot. This is essential for a redistribution of care work and a prerequisite for gender equality. In this vein, Lombardozzi argues for targeted policy to deal with gendered redistribution of unpaid labour around the activities of social reproduction and care provision. In this respect she draws on Sage's argument for targeted responses as a more effective way to achieve a more creative reform of what many still regard as male breadwinner models; for example, targeted guaranteed income schemes to enable men and women to fulfil caring obligations and responsibilities without significant economic penalties. We argue PI has potential to open what Lombardozzi terms 'more heterogenous and fluid mechanisms of social protection and public goods' (2020: 321). As Craig (2008) argues, much of this reproductive work, particularly care responsibilities, already happens in an unpaid context and the question is not so much how to make care work 'paid work' - rather, how to find time to do it in one's personal life but also how to ensure such work is equitably shared not only between parents but across society. 


\section{A targeted or universal payment?}

Beyond the question of the participation requirements that a PI should be conditioned upon, there is also the question of whether a PI should be targeted by 'conditions of circumstance' (Clasen and Clegg, 2007: 167) or universally paid to everyone. Hiilamo and Komp (2018) argue that a PI can be compatible with means-testing, although Aktinson's original proposal saw $\mathrm{PI}$ as a substitute for means-tested social assistance but not necesssarily a wholly universal payment. Rather than a payment everyone would receive, he proposed PI as a complementary form of social security in which reformed and expanded social insurance payments would remain the default form of social security for many. In this section we argue that while a PI need not be universal, only ex-post income testing, with relatively high income thresholds, can enable a PI to be administered without stigma.

Atkinson's key objection to means-testing is that it is applied at a household level, thereby penalising not just the recipients' efforts but those of his or her family as well. Another important concern is the potential to stigmatise recipients, insofar as residualising welfare through narrow means-testing may symbolically stigmatise claiming benefits as a dependent and impoverished social identity. The process of claiming benefits can itself give rise to what Baumberg (2015: 183) term's 'claims stigma' if conditions of conduct and circumstance give rise to a lack of privacy 'and the feeling of being looked down on by suspicious staff'. This, in turn, can create benefit take-up issues among those who might need welfare the most (Atkinson, 1996: 68). The force of these concerns will depend on how narrowly eligibility conditions are targeted: whether they are designed to 'screen in' only the neediest or to 'screen out' only the most affluent. A PI that recognises a wide plurality of participation and which is tapered in line with salary earnings at an individualised, modest-to-high threshold may mitigate these concerns about stigmatisation, while making any PI scheme more affordable and therefore feasible.

This emphasis on the individualisation of payments is one essential feature that a PI shares with a UBI and is an essential prerequisite for economic independence for women. The administrative specificities of how a PI can be implemented as a targeted payment along these lines will need to be determined in each national social security system, although certain Covid-19 income supports such as Ireland's Pandemic Unemployment Payment demonstrate how eligibility can be assessed ex-post and without navigating invasive administrative hurdles (see Hick and Murphy, 2021). This is not to underplay the critical importance of resolving these difficult questions; the administrative specificities are closely related to political feasibility. As Wolff (1998: 97) argues in the context of normative justifications for welfare conditionality more broadly, 'egalitarians must be concerned not only by a concern for fairness, but also by the idea of respect for all.' Forms of income support that are ideal from a normative standpoint can only be implemented via administrative systems that preserve recipients' self-respect. This is especially so for a capabilities-oriented social policy animated by a relational theory of democratic equality. It requires that recipients are not subjected to invasive bureaucratic examinations to determine eligibility and deservingness.

\section{Conclusion}

Welfare architectures, through their (de)commodifying effects, structure the boundaries between the market and the state to pattern people's participation in production and 
consumption. Social policies can therefore play an important role in accelerating ecological transitions, although the intersection between welfare and ecological sustainability remains at the margins of social policy debates. This is now changing as concepts of 'sustainable welfare' and an 'eco-social' state gain in focus and attention. Nevertheless, the particular social security reforms that might propel any shift towards an eco-social state have yet to be considered in detail. We have suggested Atkinson's concept of a PI as one reform that offers such potential, especially when allied to UBS and the collective provision of those foundational goods and services that underwrite human flourishing.

Atkinson offered PI as a compromise between what he argued were politically unfeasible aspirations for unconditional payments and the then emerging political acceptability of the workfare model, with a more conditional and producutivist welfare at its heart. Castles (2010), in reflecting on welfare reform at times of crisis, suggests that emergencies (or black swans), while once a major catalyst in shaping young welfare states, are no longer a major factor shaping welfare state development. Like 'elephants on the move', welfare states are 'rarely significantly thrown off course by particular events' (Castles, 2010: 92). We clearly argue for PI as a 'first-best' solution while acknowledging that, for those interested in UBI, it also leaves the door open for ongoing reform. While UBI has enjoyed a renaissance, if Castles is correct, proponents of a UBI might be disappointed. The implications of Castles' analysis resonate with what Atkinson first observed; that a PI offers a political halfway house between a highly conditional welfare system and fully unconditional one. For that reason, it might be politically more feasible and thus a more realistic focus for immediate reform. Atkinson also stressed how $\mathrm{PI}$ is compatible, theoretically and conceptually, with retaining social insurance as the default system of social security for many. To this extent, we have argued, it can be envisaged in targeted rather than universal terms, increasing its affordability and reducing the potential for enhanced income supports to divert resources away from the provision of UBS. Put differently, PI offers an individualised income guarantee for those without sufficient social insurance or employment earnings, which is distinct from a universal cash benefit paid to all regardless of circumstance. This brings the possibility of more immediate reform towards an eco-social state that values people's freedom 'to 'get a life' and refuse the political and cultural call to simply 'get a job" (Marston and Peterie, 2020: 44).

The opportunity for a PI and welfare system to be non-stigmatising is crucial in that it offers the possibility for wide ranging interests to coalesce around it, with alliances between unions, feminists, environmentalists and anti-poverty organisations, the type of political dynamic that Fraser, 2013) has termed a triple movement. However, it remains the case in most instances, as in the Dutch example discussed above, that the range of participation options are narrow and overly restrict people's 'navigational agency' to choose between multiple socially valuable 'doings' and 'beings'. The tighter the list of officially sanctioned activities the greater the danger that a PI will simply reproduce the stigmatising tendencies of conventional means-tested, work-conditional payments (De Wispelaere and Stirton, 2018). If PI is to avoid this prospect, it will need to be implemented through recalibrated administrative structures that focus on catalysing participation by appealing to people's intrinsic motivations and the quality and diversity of available opportunities rather than monitoring and sanctions. 


\section{Acknowledgments}

This research has received funding from the European Union's Horizon 2020 research and innovation programme under the Marie Sklodowska-Curie grant agreement no. 841477. The views expressed are those of the author alone. Neither Maynooth University nor the European Commission are responsible for any use that may be made of the information in this article.

\section{Notes}

1 Sen is famously reluctant to specify any predetermined list of capabilities as foundational to wellbeing, arguing that the conditions for flourishing vary between societies, and that any detailed list of capabilities must be subject to democratic deliberation and agreement (Sen, 2009: 241-2).

\section{References}

Anand, S. and Sen, A. (2000) 'Human development and economic sustainability', World Development 28, 12, 2029-49.

Anderson, E. (1999) 'What is the point of equality?', Ethics, 109, 2, 287-337.

Anderson, E. (2004) 'Welfare, work requirements, and dependant-care', Journal of Applied Philosophy, 21, $3,243-56$.

Atkinson, A. (1996) 'The case for a participation income', The Political Quarterly, 67, 1, 67-70.

Barry, J. (2019) 'Green republicanism and a 'just transition' from the tyranny of economic growth', Critical Review of International Social and Political Philosophy, doi: 10.1080/13698230.2019.1698134.

Baumberg, B. (2015) 'The stigma of claiming benefits: a quantitative study', Journal of Social Policy, 45, 2, $181-99$.

Beck, U. (2000) The Brave New World of Work, Cambridge: Polity Press.

Bohnenberger, K. (2020) 'Money, vouchers, public infrastructures? A framework for sustainable welfare benefits', Sustainability, 12, 2, 596.

Bonvin, J-M. and Ziegler, H. (2020) 'Social services, democracy and the capability approach: concluding reflections', Social Work and Society, 18, 1.

Brodkin, E. Z. and Larsen, F. (2013) 'The policies of workfare: at the boundaries between work and the welfare state', in E. Z. Brodkin and G. Marston (eds.), Work and the Welfare State, Copenhagen: Djørf, $57-68$.

Castles, F. G. (2010) 'Black swans and elephants on the move: the impact of emergencies on the welfare state', Journal of European Social Policy, 20, 2, 91-101.

Claassen, R. (2018) Capabilities in a Just Society: A Theory of Navigational Agency, Cambridge: Cambridge University Press.

Clasen, J. and Clegg, D. (2007) 'Levels and levers of conditionality: measuring change within welfare states', in J. Clasen and N Siegel (eds.), Welfare State Change: The Dependent Variable, Cheltenham: Elgar, 166-97.

Coote, A. (n.d.) 'Towards a sustainable welfare state: the role of universal basic services', Social Policy and Society. Forthcoming in special thematic section on 'Towards a sustainable welfare state.'

Coote, A. (2000) 'Universal basic services and the foundational economy', Foundational Economy Collective: Working Paper No.7, https://foundationaleconomycom.files.wordpress.com/2020/10/ ubs-and-fe-working-paper-wp7.pdf [accessed 08.06.2021]

Coote, A. and Lawson, N. (2021) 'Post-Covid Britain needs a new social guarantee', https://www. theguardian.com/commentisfree/2021/mar/11/post-covid-britain-new-social-guarantee-universal-basicincome-pandemic [accessed 08.06.2021].

Coote, A. and Percy, A. (2020) The Case for Universal Basic Services, Cambridge: Polity Press. 
Craig, L. (2008) 'Valuing by doing: policy options to promote sharing the care,' Journal of the Association for Research on Mothering, 10, 1, 45-56.

De Wispelaere, J. and Stirton, L. (2018) 'The case against participation income: political, not merely administrative', Political Quarterly, 89, 2, 262-67.

Doyal, L. and Gough, I. (1991) A Theory of Human Need, London: Macmillan Education UK.

Fitzpatrick, T. (2003) After the New Social Democracy: Social Welfare for the $21^{\text {st }}$ Century, Machester: Manchester University Press.

Fitzpatrick, T. (2004) 'A post-productivist future for social democracy?', Social Policy and Society, 3, 3, $213-22$.

Fraser, N. (2013) 'A triple movement? Parsing the politics of crisis after Polanyi', New Left Review, 81, $119-32$.

Goodin, R. E. (2001) 'Work and welfare: towards a post-productivist welfare regime', British Journal of Political Science, 31, 1, 13-39.

Gough, I. (2013) 'Carbon mitigation policies, distributional dilemmas and social policies', Journal of Social Policy, 42, 2, 191-213.

Gough, I. (2014) 'Lists and thresholds: comparing the Doyal-Gough theory of human need with Nussbaum's capabilities approach', in F. Comim and M. C. Nussbaum (eds.), Capabilities, Gender, Equality: Towards Fundamental Entitlements, New York: Cambridge University Press, 357-82.

Gough, I. (2015) 'Climate change and sustainable welfare: the centrailty', Cambridge Journal of Economics, $39,5,1191-1214$.

Gough, I. (2019) 'Universal basic services: a theoretical and moral framework', Political Quarterly, 90, 3, $534-42$.

Gough, I. (2020) 'In times of climate breakdown, how do we value what matters?', https://www. opendemocracy.net/en/oureconomy/times-climate-breakdown-how-do-we-value-what-matters/ [accessed 25.06.2020].

Groot, L., Muffels, R. and Verlaat, T. (2019) 'Welfare states' social investment strategies and the emergence of Dutch experiments on a minimum income guarantee', Social Policy and Society, 18, 2, 277-87.

Haberl, H., Wiedenhofer, D., Virág, D., Kalt, G., Plank, B., Brockway, P., Fishman, T., Hausknost, D., Krausmann, F., Leon-Gruchalski, B., Mayer, A., Pichler, M., Schaffartzik, A., Sousa, T., Streeck, J. and Creutzig, F. (2020) 'A systematic review of the evidence on decoupling of GDP, resource use and GHG emissions, part II: synthesizing the insights', Environmental Research Letters, 15, 6, 65003.

Hick, R. and Murphy, M. P. (2021) 'Common shock, different paths? Comparing social policy responses to COVID-19 in the UK and Ireland', Social Policy and Administration, 55, 2, 312-25.

Hiilamo, H. and Komp, K. (2018) 'The case for a participation income: acknowledging and valuing the diversity of social participation', Political Quarterly, 89, 2, 256-61.

Hirvilammi, T. (2020) 'The virtuous circle of sustainable welfare as a transformative policy idea', Sustainability, 12, 1, 391.

Hirvilammi, T. and Koch, M. (2020) 'Sustainable welfare beyond growth', Sustainability, 12, 1.

Koch, M. (2018) 'Sustainable welfare, degrowth and eco-social policies in Europe', in B. Vanhercke, D. Ghailani and S. Sabato (eds.), Social Policy in the European Union: State of Play 2018, Brussels: European Trade Union Institute and European Social Observatory, 37-52.

Koch, M. and Fritz, M. (2014) 'Building the eco-social state: do welfare regimes matter?', Journal of Social Policy, 43, 4, 679-703.

Laruffa, F. (2020) 'What is a capability-enhancing social policy? Individual dutonomy, democratic citizenship and the insufficiency of the employment-focused paradigm', Journal of Human Development and Capabilities, 21, 1, 1-16.

Laurent, E. (2020) 'The four worlds of the social-ecological state', https://www.socialeurope.eu/the-fourworlds-of-the-social-ecological-state [accessed 25.06.2020].

Leaver, A. and Williams, K. (2014) 'After the 30-year experiment: the future of the 'foundational economy', Juncture, 21, 3, 215-21. 
Lombardozzi, L. (2020) 'Gender inequality, social reproduction and the universal basic income', Political Quarterly, 91, 2, 317-23.

Marston, G. and Peterie, M. (2020) 'Is universal basic income a desirable alternative to conditional welfare?', Social Alternatives, 39, 1, 39-46.

McKay, A. (2001) 'Rethinking work and income maintenance policy: promoting gender equality through a citizens' basic income', Feminist Economics, 7, 1, 97-118.

Muffels, R., Gielens, E. and Vos, S. (2019) 'Job search, employment capabilities and well-being of people on eelfare in the Dutch 'participation income' experiments', in E. Muffels and E. Gielens (eds.), Empirical Research on an Unconditional Basic Income in Europe, Cham: Springer, 109-38.

Nussbaum, M. (2001) Women and Human Development: The Capabilities Approach, New York: Cambridge University Press.

Panitch, V. (2011) 'Basic income, decommodification and the welfare state', Philosophy and Social Criticism, 37, 8, 935-45.

Patrick, R. (2017) 'Wither social citizenship? Lived experiences of citizenship in/exclusion for recipients of out-of-work benefits', Social Policy and Society, 16, 2, 293-304.

Pérez-Muñoz, C. (2016) 'A defence of participation income', Journal of Public Policy, 36, 2, 169-93.

Pérez-Muñoz, C. (2018) 'Participation income and the provision of socially valuable activities', Political Quarterly, 89, 2, 268-72.

Pinto, J. (2020) 'Green republicanism and the shift to post-productivism: a defence of an unconditional basic income', Res Publica, 26, 2, 257-74.

Rawls, J. (1999) A Theory of Justice [Revised Edition], Cambridge, MA: Harvard University Press.

Robeyns, I. (2001) 'Will a basic income do justice to women?', Analyse und Kritik, 23, 1, 88-105.

Sayer, A. (2019) 'Moral economy, the foundational economy and de-carbonisation', Renewal: A Journal of Labour Politics, 27, 2, 40-46.

Sen, A. (2009) The Idea of Justice, Cambridge, MA: Belknap Press.

Stamm, I., Matthies, A. L., Hirvilammi, T. and Närhi, K. (2020) 'Combining labour market and unemployment policies with environmental sustainability? A cross-national study on ecosocial innovations', Journal of International and Comparative Social Policy, 36, 1, 42-56.

Swaton, S. (2018) 'For an ecological transition income', https://www.greeneuropeanjournal.eu/for-anecological-transition-income/ [accessed 18.01.2021].

van Parijs, P. (1995) Real Freedom for All: What (If Anything) Can Justify Capitalism?, Oxford: Oxford University Press.

White, S. (2017) 'Should a minimum income be unconditional?', in S. Civitarese and S. Halliday (eds.), The Fate of Social Welfare in an Age of Austerity: Socio-Economic Rights in Europe, London: Routledge, 181-96.

Wignaraja, K. and Horvath, B. (2020) 'Universal basic income is the answer to the inequalities exposed by COVID-19', https://www.weforum.org/agenda/2020/04/covid-19-universal-basic-income-socialinequality/ [accessed 26.06.2020].

Wolff, J. (1998) 'Fairness, respect, and the egalitarian ethos', Philosophy and Public Affairs, 27, 2, 97-122. 